\title{
WAVE IMPACT AND DUNE EROSION DURING HURRICANE MATTHEW
}

\author{
Britt Raubenheimer, Woods Hole Oceanographic Institution, britt@whoi.edu \\ Steve Elgar, Woods Hole Oceanographic Institution, elgar@whoi.edu \\ Kate Brodie, U.S. Army Engineer Research \& Development Center, Katherine.L.Brodie@usace.army.mil \\ Nick Spore, U.S. Army Engineer Research \& Development Center, Nicholas.J.Spore@usace.army.mil \\ Levi Gorrell, Woods Hole Oceanographic Institution, Igorrell@whoi.edu \\ Annika O’Dea, Oregon State University, odeaa@oregonstate.edu
}

\section{INTRODUCTION}

Extreme storms can cause rapid morphological changes that pose high risk to society (Sallenger 2000). Semiempirical and process-based models often are used to simulate storm-induced coastal processes (Roelvink et al. 2009, Palmsten \& Holman 2012, Stockdon et al. 2014, Overbeck et al. 2017). However, there are few observations of surfzone waves and currents during extreme storms. Therefore, parameterizations often are calibrated by minimizing model-data errors for pre- to post-storm bathymetric and topographic changes, and the accuracy of the simulated processes during the storm is unknown. Here, surf, swash, and dune observations collected near Duck, NC, USA, will be used to investigate wave processes and dune erosion during the passage of recent (2015-2017) Hurricanes.

\section{FIELD OBSERVATIONS}

Maximum offshore wave heights in 17-m water depth were about $5.2 \mathrm{~m}$ on Oct 09,2016 . Surfzone waves and currents and wave runup were measured from Sep 27 until Oct 24 with a directional array in 8-m water depth (not shown), and with pressure gages, current meters, current profilers, and lidars (mounted on the dune) on two cross-shore transects separated by about $370 \mathrm{~m}$ in the alongshore (Figure 1). Dune and beach topography were measured hourly with the two dune-mounted lidars and with an additional landward-looking lidar mounted on a nearby pier, providing coverage of $\sim 500 \mathrm{~m}$ along the shoreline. Bathymetric surveys between the dune toe and $8 \mathrm{~m}$ depth $(550<$ alongshore distance $<1100 \mathrm{~m}$, Figure 1) were conducted on Sep 26, Oct 03, and Oct 20. In addition, altimeters in $2.5,3.0$, and $4.0 \mathrm{~m}$ depth measured sand levels continuously on the northern transect $(y=950 \mathrm{~m})$. Offshore water levels (owing to tides and storm surge) were measured with a NOAA tide gauge at the end of the pier (6-m water depth), and winds were measured on the pier.

Wave runup collided with the dune during the highest water levels (dune collision regime), but waves did not overtop the dune system (the dune crest is about $7 \mathrm{~m}$ above mean sea level). Erosion occurred near the toe of the dune, where vegetation is minimal, and the dune face and crest collapsed in some locations Dune erosion was confined to a roughly $100-\mathrm{m}$ wide region onshore of the southern instrument transect (Figure 1). The dune elevation was lower and the swashzone beach was wider where the beach and dune were stable than where erosion was significant.

\section{DISCUSSION}

The hurricane observations will be used to investigate parameterizations and semi-empirical models for waves, swash, setup, and morphological change. In particular, there are few storm-regime field tests of the parameterizations for wave-height-to-depth ratios, wave asymmetries, and runup and setup that are used in semi-empirical and process-based models. Swash observations will be compared with prior studies that suggest infragravity fluctuations may (Guedes et al. 2013), or may not (Fiedler et al. 2015) become saturated during storms. Wave reflection during dune collision, and the effects of reflection on swash and inner-surf processes, will be examined. The observations also will be used to evaluate if semi-empirical models reproduce the alongshore variability in dune erosion.

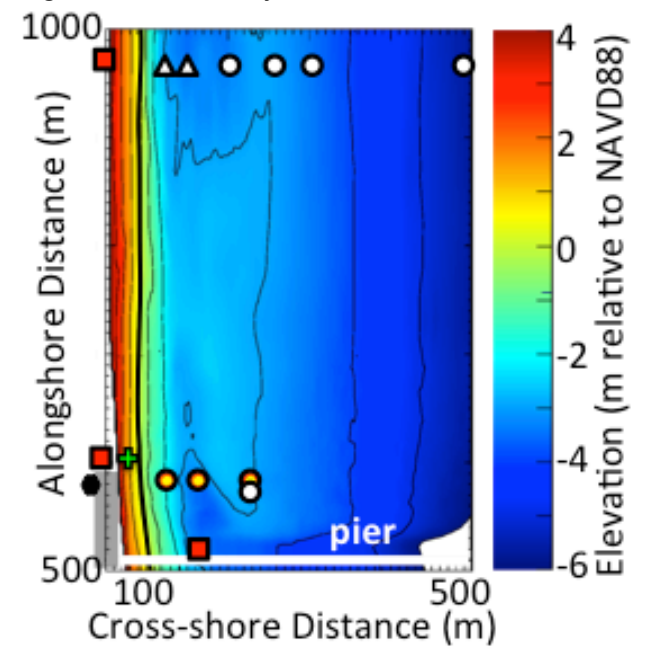

Figure 1- Bathymetry contours (black curves every $\mathrm{m}$ in elevation and colors, scale on right) vs cross- and alongshore distances (beach on the left) measured on Sep 26, 2016, and surfzone instruments during Hurricane Matthew: lidars (red squares), pressure gages (white triangles), wave and current profilers (white circles), wave and current meters (yellow bull's eyes), ultrasonic altimeter (green plus), and video tower (black polygon). The thick black curve separating green-blue contours from yellow-red contours is $0 \mathrm{~m}$ NAVD88. The gray shaded area (lower left along y-axis) is the region with the highest dune erosion rate.

\section{REFERENCES}

Fiedler, Brodie, McNinch, Guza (2015): Geophys. Res. Lett. 42, 9933-9941.

Guedes, Bryan, Coco (2013): J. Geophys. Res. 118, 3651-3669.

Overbeck, Long, Stockdon (2017): Geophys. Res. Lett., 44, 937-945

Palmsten, Holman (2012): Coast. Eng. 60, 123-135.

Roelvink et al. (2009): Coast. Eng. 56, 1133-1152.

Sallenger (2000): J. Coast. Res. 16, 890-895.

Stockdon, Thomson, Plant, Long (2014): Coast. Eng. 92, 1-11.

Funded by $A S D(R \& E)$, USACE, NSF 